\title{
Article \\ Stone Architectural Decoration in Burji Era: The Northern Mausoleum in the Khanqah of Al-Nasir Faraj Ibn Barquq (Cairo). Contribution to the Knowledge and Conservation Assessment
}

\author{
Alba Patrizia Santo ${ }^{1}$, Francesco Di Benedetto ${ }^{2}{ }^{\circledR}$, Carlo Alberto Garzonio ${ }^{1}\left(\mathbb{D}\right.$, Elena Pecchioni ${ }^{1}$, \\ Teresa Salvatici $^{1}$ (D) and Michele Coppola ${ }^{3, *(D)}$ \\ 1 Department of Earth Sciences, University of Florence, Via G. La Pira 4, 50121 Florence, Italy; \\ alba.santo@unifi.it (A.P.S.); carloalberto.garzonio@unifi.it (C.A.G.); elena.pecchioni@unifi.it (E.P.); \\ teresa.salvatici@unifi.it (T.S.) \\ 2 Department of Physics and Earth Science, University of Ferrara, Via G. Saragat 1, 44122 Ferrara, Italy; \\ francesco.dibenedetto@unifi.it \\ 3 Department of Architecture, University of Florence, Via della Mattonaia 14, 50121 Florence, Italy \\ * Correspondence: michele.coppola@unifi.it
}

check for updates

Citation: Santo, A.P.; Di Benedetto,

F.; Garzonio, C.A.; Pecchioni, E.;

Salvatici, T.; Coppola, M. Stone

Architectural Decoration in Burji Era:

The Northern Mausoleum in the

Khanqah of Al-Nasir Faraj Ibn

Barquq (Cairo). Contribution to the

Knowledge and Conservation

Assessment. Heritage 2021, 4, 507-523.

https: / / doi.org/10.3390/

heritage 4010030

Received: 23 February 2021

Accepted: 13 March 2021

Published: 16 March 2021

Publisher's Note: MDPI stays neutral with regard to jurisdictional claims in published maps and institutional affiliations.

Copyright: (c) 2021 by the authors. Licensee MDPI, Basel, Switzerland. This article is an open access article distributed under the terms and conditions of the Creative Commons Attribution (CC BY) license (https:/ / creativecommons.org/licenses/by/ $4.0 /)$.

\begin{abstract}
The conservation of monuments in Cairo represents a complex matter, influenced by the cultural context, the intrinsic features of a vast and heterogeneous architectural heritage, and the environmental conditions. Monument vulnerability levels strongly need to be systematized to delineate adequate programs of control, management, and intervention. Despite their leading role in the Egyptian architectural heritage, many monuments experience a critical state of conservation. Here, we report the results of a multi-scale investigation of the northern mausoleum in the complex of the Khanqah of Al-Nasir Faraj Ibn Barquq, located in the Islamic cemetery of Al-Qarafa Al-Kubra (Cairo, Egypt). Our research aims to increase the knowledge on the decorative stones used in the mausoleum and their decay processes. The investigation has been focused on the two areas of the building covered by a colored stone-slabs pattern: the floor and the qibla wall. A detailed architectural survey, carried out through photogrammetric techniques, provided a three-dimensional morphological knowledge of the mausoleum, upgrading the available surveys made about 50 years ago. The distribution of the materials has been verified by visual analysis, integrated by the first detailed mineralogical and petrographic characterization made on this mausoleum. The digital survey of the stone surfaces and the mineralogical, chemical, and petrographic analyses allowed a systematic mapping of the decay phenomena and some insights on the morphological alteration of single elements. The obtained results indicate a capillary rise of groundwaters and airborne pollution as the main degradation processes.
\end{abstract}

Keywords: Cairo; Burji architecture; Al-Nasir Faraj; khanqah; Mamluk architectural decoration; ornamental stone decay; stone conservation; XRD; ATR-FTIR; compositional characterization

\section{Introduction}

The intense building activity of the Mamluk sultans and their entourage led to a wide architectural reconfiguration of the city of Cairo [1]. Many historians and chroniclers (from Ibn Khaldun to Maqrizi), between the 14th and 15th centuries, exalted the splendor of this built scenario, indicating the high level of awareness of its cultural value [2]. The history of Egyptian architecture is marked by a deep link with stone technology, in a varied range of methods of use and processing [3]. In the Mamluk era, the primacy of stone was re-affirmed over other perishable materials (unfired bricks, plaster, wood, etc.) and has indelibly marked the architectural features of the monumental production of the sultans, especially with the systematic use of polychrome ornamental stones [4,5]. Mamluk 
monuments are the most consistent and representative ensembles of Cairo's architectural heritage. This has inevitably placed them at the center of the conservation initiatives undertaken in the city between the 19th and 20th centuries [6]. In 1979, the inscription of Historic Cairo in the Unesco World Heritage List underlined the need for wide conservation actions by marking the apex of its cultural recognition [7].

The conservation problems of such a large architectural heritage range from structural maintenance to stone conservation, from functional rehabilitation to the improvement of social perception. Consequently, several different situations can be envisaged, where two or more of the main issues mentioned above need to be considered together. General threats to the maintenance and accessibility of most sites have been identified in recent decades in the capillary rise of groundwater [8-10] and the increase in aerosol pollution [11,12]. Both phenomena are linked to the enormous demographic growth that Cairo underwent in the last half-century. The strong cultural and documentary value of the stone decorations of the Mamluk era constitutes their main identity and makes their conservation a crucial factor. This aspect has influenced all the restoration interventions carried out on the monuments, often leading to the restoration through a systematic replacement of the deteriorated elements $[13,14]$. The inadequate superimpositions of modern and original stones, however, pose problems of material and aesthetic authenticity and compatibility. The need for greater attention to this issue is becoming increasingly relevant, not only to clarify the different ways of decay but also to define timely and appropriate restoration/replacement interventions. A strong contribution in this sense was provided by James Harrell's systematic studies on these stone structures [15].

This study, carried out in collaboration between the University of Florence and the General Union of Arab Archaeologists, aims to contribute to the knowledge and preservation of Al-Nasir Faraj Ibn Barquq's khanqah complex. The building is a good representative case of the conditions in which many other monuments in the area are found [16].

In the initial phase of our research, it was decided to concentrate the study activities on the Northern mausoleum, to extend the future investigation to the entire architectural complex. Moreover, the general long-term project is to export the process and the results obtained to other abandoned monuments of the Mamluk era in the al-Qarafah al-Khubra area. The research was developed following an integrated methodological approach (multi-scale and multi-disciplinary) consisting of (a) the study of paper sources for the reconstruction of the history of transformations, (b) the architectural survey for morphological knowledge and (c) the identification of stone materials and related deterioration processes.

Here we present the preliminary results obtained on the decorative stone coating of the northern mausoleum, which constitutes one of the most characterizing features of the buildings of this era. The intersection of existing information with that obtained from the detailed survey of the stone surfaces made it possible to map the existing materials and start identifying the original and replaced elements in previous interventions. On this basis of work, the in-depth analysis of the materials was carried out through a mineralogical, and petrographic characterization of the collected rock samples.

\section{The Complex of the Sultan Al-Nasir Faraj Ibn Barquq in the Al-Qarafah Al-Kubra District}

The Al Nasir Faraj Ibn Barquq khanqah complex is located in the northern part (AlKubra) of the historic district-cemetery of Al-Qarāfah, which occupies a sub-flat area between the medieval city of Cairo and the heights of Mokattam (Figure 1). This area, originally desert, was chosen as the site of a necropolis since the foundation of Al-Fustat and its funerary vocation was also promoted in the Fatimid and Ayyubid times $[17,18]$. In the Mamluk era, the area acquired an increasingly urban and monumental dimension $[19,20]$. 


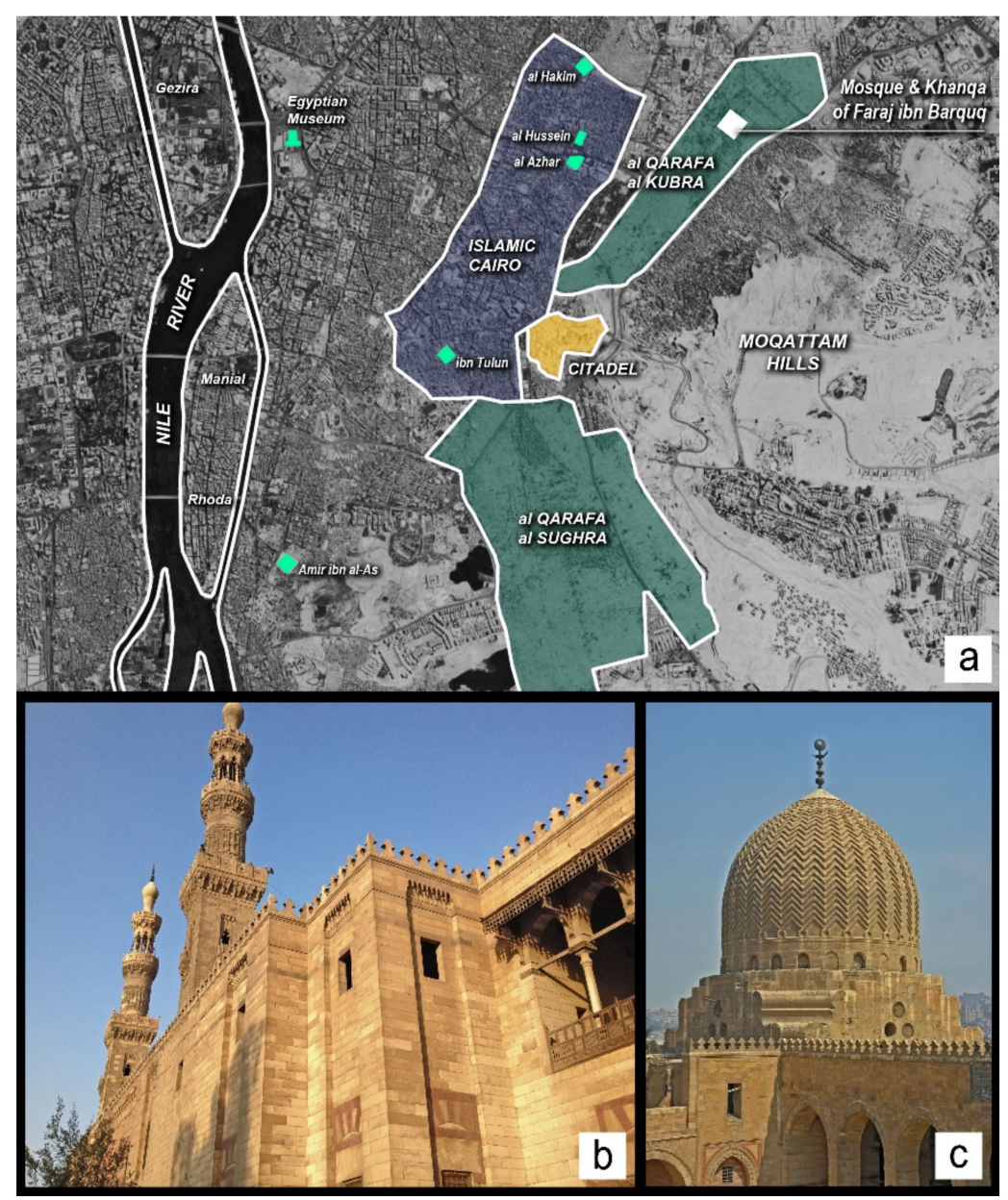

Figure 1. (a) Localization of the Faraj Ibn Barquq; (b) view of the western façade of the complex; (c) the stone-carved dome.

Sultan Al-Malik Al-Zahir Sayf ad-Din Barquq (1382-1399), the first ruler of the Burji dynasty, wanted to be buried in Al-Qarāfah Al-Kubra, next to the tombs of Sufi shaykhs [21]. The project involved a large building complex developed around the mausoleum of the royal family and the khanqah, with several service buildings [22,23]. Sultan Al-Nasir Faraj, son of Barquq, actually began and completed the complex in 1412 [24]. Several sources indicate a certain Cherkis al Haranbuli as the architect who created this "multifunctional" monumental complex [24]. In the Burji period, the building was the place of intense attendance linked to the monastic life of the Sufis, the activities of its Koranic schools but also devotional pilgrimage initiatives and commemorative celebrations. Further works on the building were carried out during the reign of Qaitbay (1468-1496) [18]. During the Ottoman rule, the building probably lost its monasterial function and was used just for normal worship [24].

The khanqah is set on a square plan of about $73 \mathrm{~m}$ on each side, in which elements of congregational mosques and madrasas are combined $[18,20]$. The single buildings composing the complex are distributed around a large square central courtyard of about $40 \mathrm{~m}$ on each side, overlooked by four iwans with arcades (Figure 2). Each of the sides corresponds to the different funeral, religious, and teaching functions, and activities for which the building was intended. The main facade, on which are symmetrically the two main entrances, is on the west side. Only the door on the southwest corner is currently in use. The south side was mainly occupied by the area for ablutions (the mida'a) and by several other service rooms. The northern wing houses the proper Khanqah (Dür as Sufiya). The east wing consists of the eastern iwan, the largest of the four, which houses the mosque, and 
which connects the two large twin mausoleums at the north and south corners, intended for male and female family members [24].

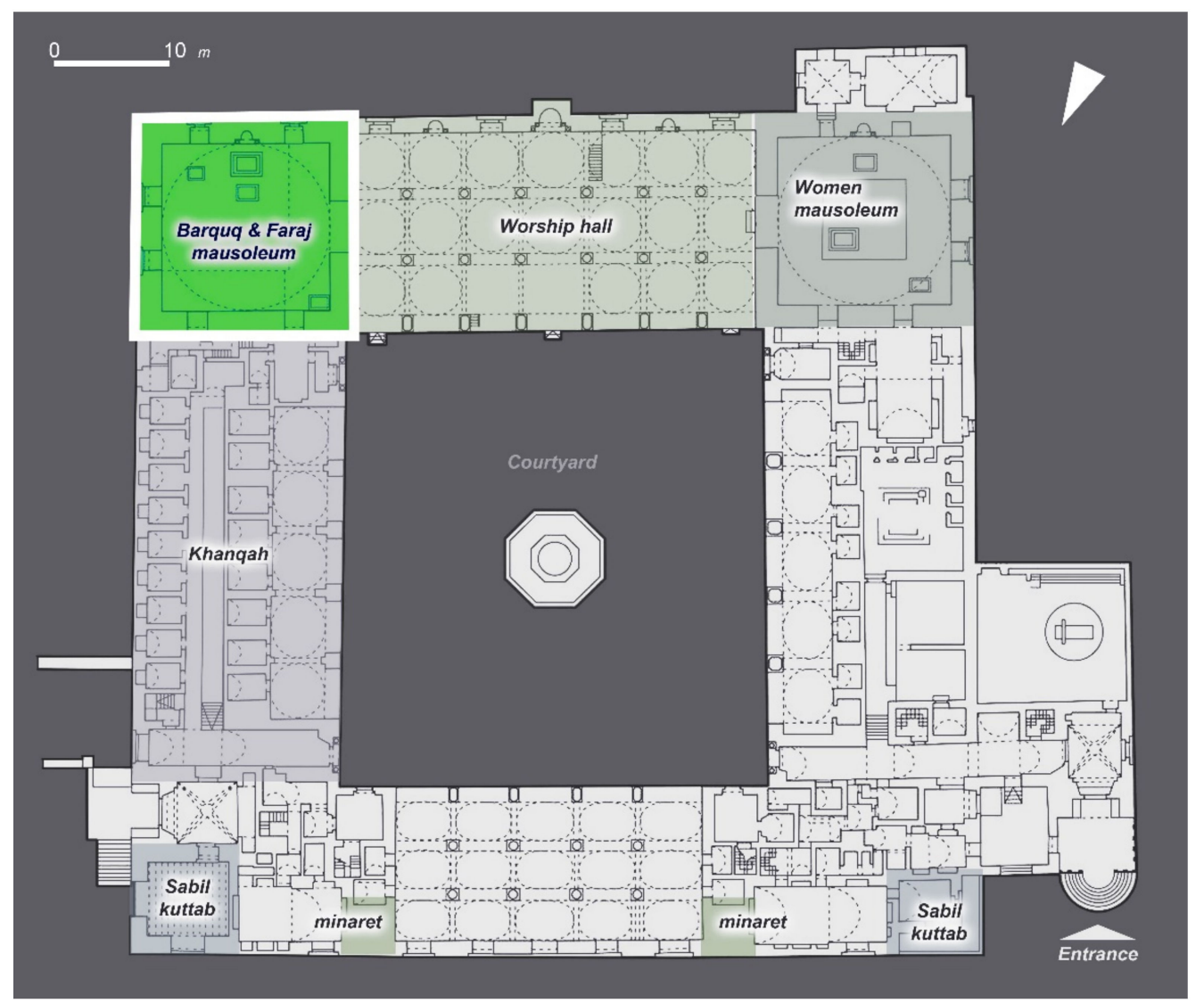

Figure 2. Plan of the Faraj Ibn Barquq complex, with reported the main sections (elaboration from Mostafa [23]). The green square corresponds to the northern mausoleum.

\section{The Northern Mausoleum}

The mausoleum is located in the North-East corner of the complex and consists of a single room with a square plan of about $14.35 \mathrm{~m}$ on each side (internal) (Figures 2 and $3 a, b$ ). The perimeter walls, $2.07 \mathrm{~m}$ thick, are made of large squared blocks of limestone [16] belonging to three main dimensional classes, the largest of which has dimensions: $\mathrm{L}=150 \mathrm{~cm}$, $\mathrm{W}=42 \mathrm{~cm}, \mathrm{H}=46.2 \mathrm{~cm}$ (1 dhira al-Yad or hand cubit) [25]. The composition of the four internal elevations can be schematized in three superimposed registers. The lower one has two windows-niches on each side, except the south wall, where the entrance to the mausoleum connects it with the mosque. The intermediate register houses the windows and is delimited below by a large frieze (tiràz) with inscriptions in golden relief on a blue background and above by a molding, both running along the entire perimeter of the mausoleum. In this space, there are two windows on each side, aligned with the lower niches. The upper register, made with smaller limestone blocks, houses a group of windows in the middle of each side and the four pendentives with muqarnas supporting the dome (Figure 3b). 


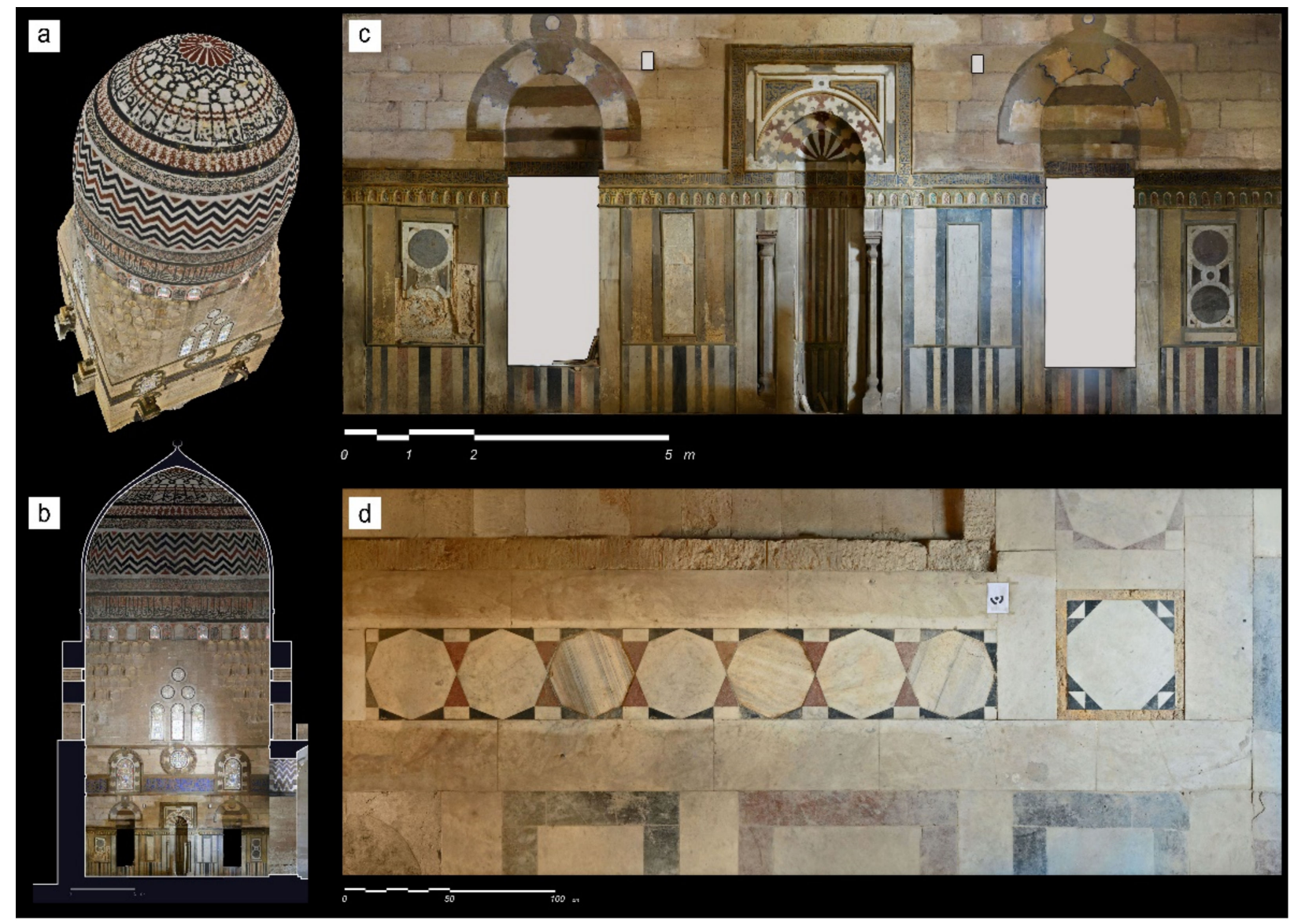

Figure 3. The northern mausoleum: (a) 3D textured model of the interior surface; (b) cross-section of the mausoleum towards the south west side; (c) elevation of the qibla wall; (d) detail of the floor decoration.

The qibla wall differs from the others for the presence of the mihrab, a large circular window in the intermediate register, and, above all, for the decoration of the lower register with a covering in polychrome stone slabs, which, according to Mostafa [24], dates back to 1405. This surface is bordered on the upper part by a marble tiràz with golden inscriptions in relief on a blue background. The area below is made up of four large rectangular sections covering the separation surface between the niches, the mihrab, and the side walls (Figure 3c). Each section is laterally delimited by two vertical slabs of white stone and is divided, through painted wooden strips, into two registers. The lower one is made up of a sequence of vertical white, red and green slabs, arranged symmetrically to a central black plate. The same pattern covers the lower plinth of the windows. The upper register is set on a large central white stone slab surrounded by a red band. Two vertical white and red plates delimit this section laterally. In the two side panels between the niches and the walls, this pattern follows a variant, with the insertion of colored circular slabs inserted in the large central white marble slab. The decoration of the mihrab has sophisticated geometric motifs, with lower blind niches overhanging and with the presence of incisions filled with red or green colored paste. Traces of these mixtures are also found on some slabs, probably to modify their coloring or, in some cases, as Mostafa [24] claims, as a preparatory layer for gilding. The floor also has a covering in polychrome ornamental stones on a perimeter band about $4 \mathrm{~m}$ deep, on which the decoration plates of the qibla wall seem to rest (Figure 3d). A difference in height of $10 \mathrm{~cm}$ separates this pavement from a central square area of $6.35 \mathrm{~m}$ on each side, covered with limestone slabs. In the mausoleum, there are four marble cenotaphs, consisting of a stepped podium on which rests a parallelepiped block. Barquq's cenotaph with its dedicatory column (as-Sähid) and that of his son Al-Mansur Abd al Aziz are decorated with painted inscriptions and reliefs. 
In the Burji era, some changes related essentially to maintenance (flooring) or use (closing of windows, new burials, and furnishings) to the building [24] can probably be traced back.

The state of neglect of the building around the middle of the 19th century led the Comité de Conservation des Monuments de l'Art Arabe to carry out, between 1884 and 1961, a series of interventions that concerned the windows, the cenotaphs, the floor, the dome, and the pictorial decorations [14,26,27]. Among the restoration work carried out by the Comité, one must highlight the total dismantling of the existing floor, the reconstruction of the bottom, and the reassembly with the replacement of all the deteriorated decorative elements [14].

\section{Architectural Survey and Morphological Documentation of the Decorated Surfaces}

The first step of the architectural documentation campaign involved a topographic survey for the recording of known points and the construction of a reliable geometric scheme. With this basic reference, it was possible to proceed with the construction of the 3D model using digital photogrammetry. Two models were produced, one for the external volume and one for the internal volume of the building (Figure 3a). The photographic documentation was systematically carried out on all internal and external surfaces of the mausoleum, with the help of optical sights automatically recognizable by processing software. The images were processed into blocks corresponding to the different parts in which the mausoleum was schematized (dome, walls, muqarnas, niches, etc.). All the portions have been combined to obtain the general 3D model of the building on which the photographic mapping of the surfaces has been applied. From the model, the individual drawings (plans, elevations, sections) were extracted (Figure 3b). For some portions (qibla wall and pavement) a high-resolution 3D model was produced and it was used for the positioning of the sampling points, surveys, and the related data (Figure $3 c, d$ ).

\section{Decay of the Stone Surfaces. General Analysis and Study of Their Distribution}

The northern mausoleum, as well as the whole complex of the Sultan Al-Nasir Faraj Ibn Barquq, displays an advanced deterioration state. All the ornamental stones exhibit extended forms of decay such as deposits, erosion, mechanical damage (Figure 4). Based on the architectural survey it was possible to analyze the distribution of the identified decay phenomena (Figure 5a). The detailed survey made it possible to document the loss of material and the consequent reduction in the volume of numerous stone elements (Figure 5b). Outside the building, the phenomenon is concentrated in the lower parts of the walls, where the fragmentation of the limestone blocks led to a retreat of the stone mass with respect to the original surface. On the internal walls of the building, the effects of this decay are less effective on the limestone blocks but are concentrated on the mortars used to prepare the cladding of the qibla wall, with the consequent detachment of some slabs. On the floor, the effects of the capillary rise are evident in the perimeter strip covered with ornamental stone slabs. The fragmentation of the material led to a marked retreat of individual elements with respect to the surface. The digital survey also highlighted widespread deformation phenomena localized in this portion of the floor, with the fracturing of many slabs. As previously mentioned, the partial reconstruction and ornamental stone replacement operated during the restoration work carried out by the Comite [14] somehow hinders the esteem of the evolutionary speed of the phenomena encountered. According to this preliminary frame, we have planned a sampling campaign for the characterization of the materials. 


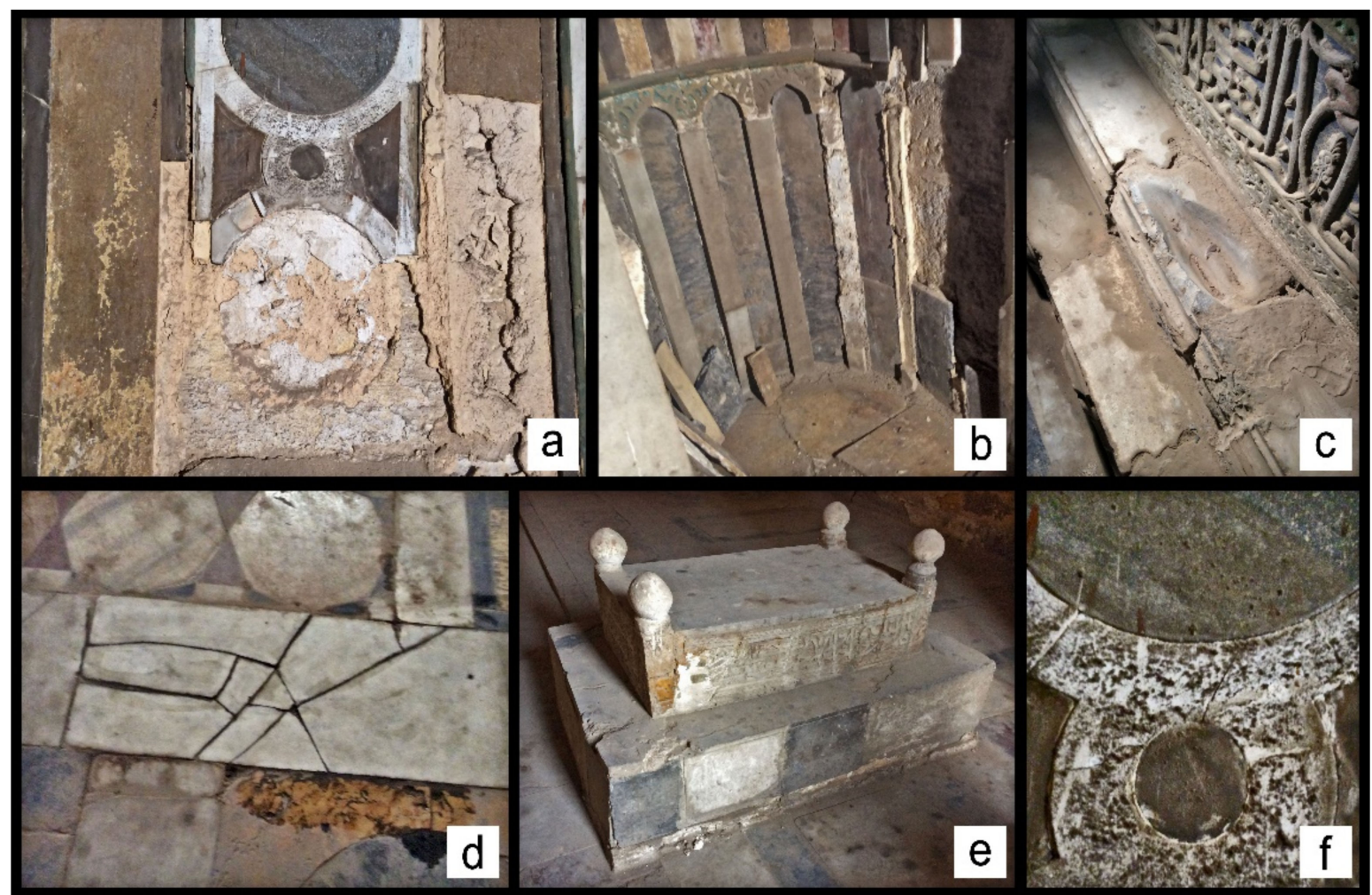

Figure 4. Different forms of deterioration in the northern mausoleum; (a) loss of material, granular disintegration, discoloration; (b) detachment of slabs; (c) fractures, erosion; (d) fractures; (e) loss of material, fractures, erosion; (f) organic staining, efflorescence.

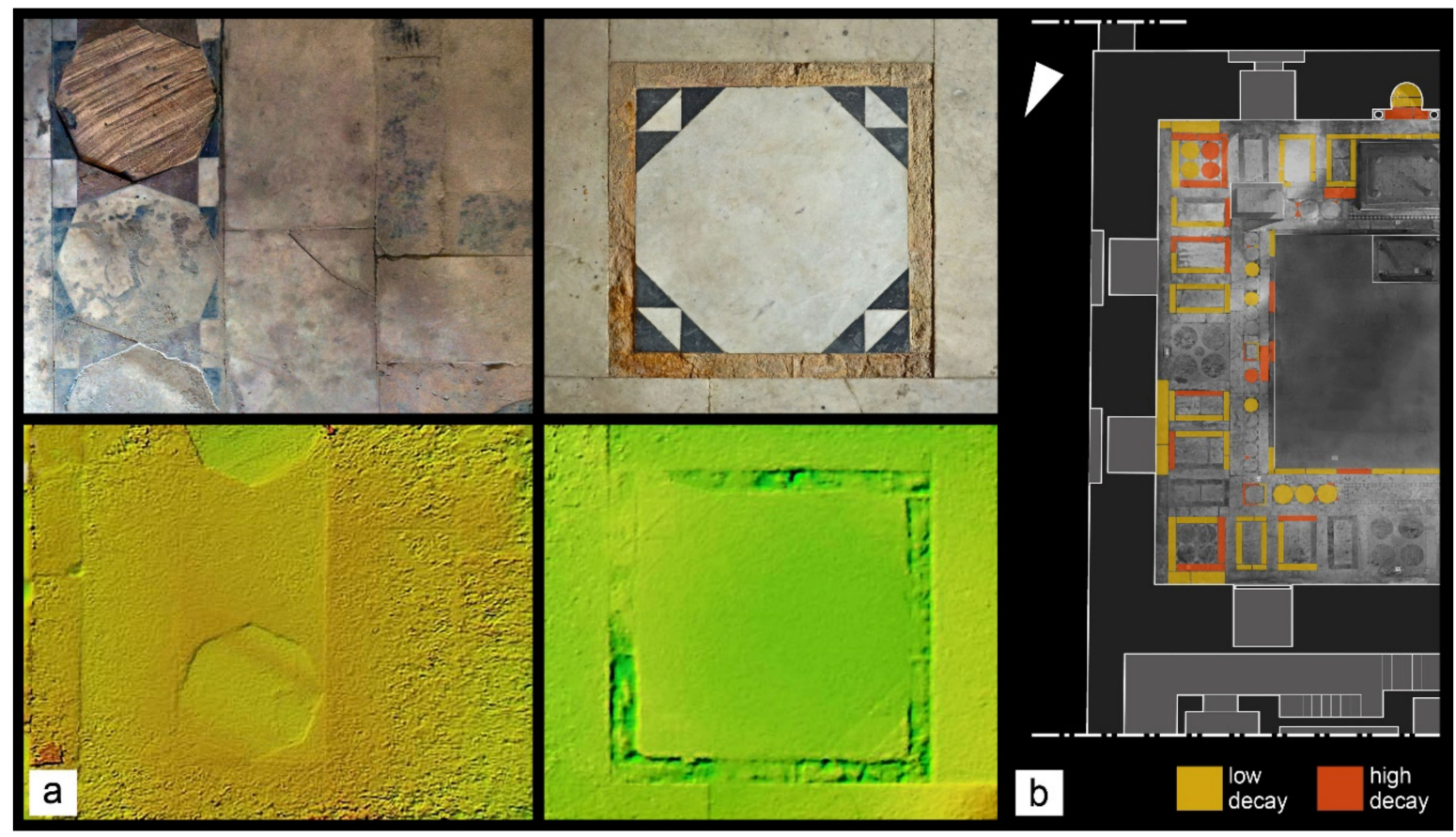

Figure 5. Documentation of the stone decay of the mausoleum floor. (a) Depth Elevation Model (DEM) of the ornamental stone surfaces highlighting the loss of material; (b) distribution of the degradation phenomena in a portion of the pavement slabs. Yellow: low decay. Orange: high decay. 


\section{Sampling and Analytical Techniques}

To decorate the qibla wall and the floor of the mausoleum, a variety of stones, displaying different colors, was used. During the sampling campaign (fall 2018), the ornamental apparatus of the northern mausoleum was sampled by the staff of the Department of the Earth Sciences of the University of Florence, assisted by the staff of the General Union of the Arab Archaeologists. Samples were collected from both the qibla wall and the floor decorations to compositionally characterize the different stones and to obtain information on the alteration products possibly present. The sampling was carried out, where possible, removing small chips of material from areas affected by fractures, cracks, and detachments. A few samples of alteration products (dust) were also sampled from the stone surfaces. A full list of the in situ sampled materials is reported in Table 1 whereas the maps of the qibla wall and floor, with the position of the collected samples, are shown in Figures 6 and 7.

Mineralogical and petrographic analyses were carried out using X-ray Diffraction (XRD) and a polarizing microscope. XRD analysis was conducted using a Philips PW $1050 / 37$ powder diffractometer, operating at $40 \mathrm{kV}, 20 \mathrm{~mA}$, with a $\mathrm{Cu}$ anode, graphite monochromator, and with $2^{\circ} / \mathrm{min}$ goniometry speed, in a scanning range between $5-70^{\circ}$ 20. Panalitycal $X^{\prime}$ PertPRO and High Score software, for data acquisition and interpretation, were utilized; the detection limit is $4 \%$. The textures of the collected samples were studied on thin sections (30 microns thickness) using a Zeiss Axio Scope.A1 polarising microscope, equipped with a camera (resolution 5 megapixel) and AxioVision image analysis software.

Fourier Transform Infrared Spectroscopy analysis (FTIR) was employed to obtain the composition of some samples (dust and patinas) through Attenuated Total Reflection (ATR) mode in a Spectrum 100 FTIR spectrometer (Perkinelmer inc., Norwalk, CT, USA). The acquisition was carried out at room temperature, in the spectral range between 4000 and $350 \mathrm{~cm}^{-1}$, repeating 4 scans with a $4 \mathrm{~cm}^{-1}$ resolution. The data were acquired and processed using Spectrum 100 software. The analyzed patinas consist of materials removed from the surfaces of the collected stone.

Table 1. Collected samples (rocks and dust) from the eastern wall and floor of the northern mausoleum.

\begin{tabular}{cccc}
\hline Sample & Provenience & Colour & Type \\
\hline MB1 & Left grave & White & Rock \\
MB2 & Left wall & Black & Dust \\
MB4 & Left wall & Black & Rock \\
MB6 & Left wall & Red & Rock \\
MB7 & Floor & Red & Rock \\
MB8 & Floor & Yellow & Rock \\
MB10 & Floor & Yellow & Rock \\
MB11 & Floor & Red & Rock \\
MB13 & Floor & Yellow & Rock \\
MB14 & Right wall & Black & Rock \\
MB15 & Mihrāb & Black & Rock \\
MB16 & Mihrāb & White & Rock \\
MB17 & Floor & Black & Rock \\
MB18 & Right wall & White & Rock \\
MB19 & Right wall & White & Rock \\
MB20 & Floor & Red & Rock \\
MB23 & Left wall & Red & Dust \\
MB24 & Mihrāb & Yellow & Rock \\
MB25 & Mihrāa & Red & Rock \\
MB26 & Floor & White & Rock \\
MB27 & Mihrāa & Red & Rock \\
MB28 & Floor & Yellow & Rock \\
\hline
\end{tabular}




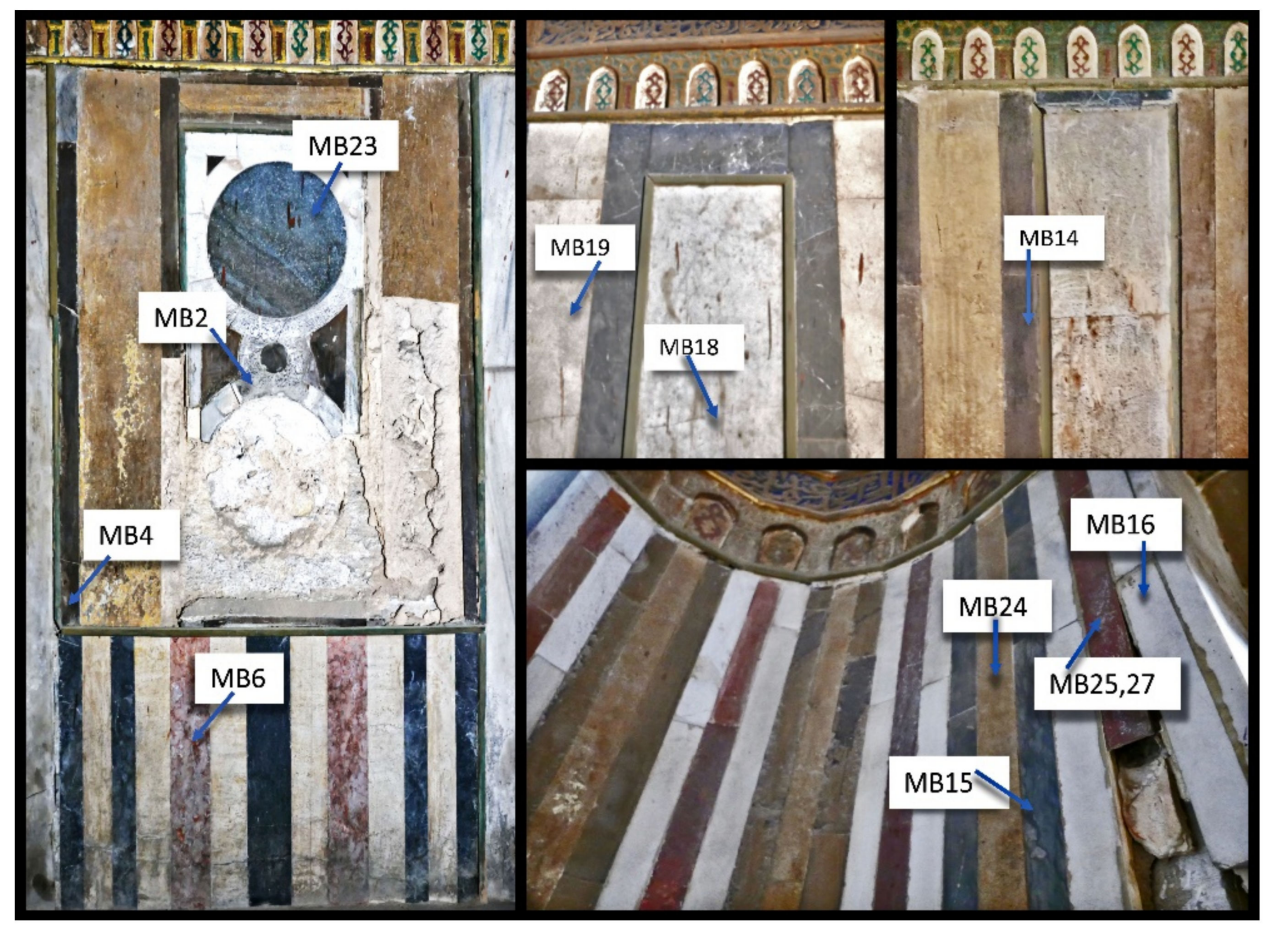

Figure 6. Mapping of the collected samples on different portions of the qibla wall.

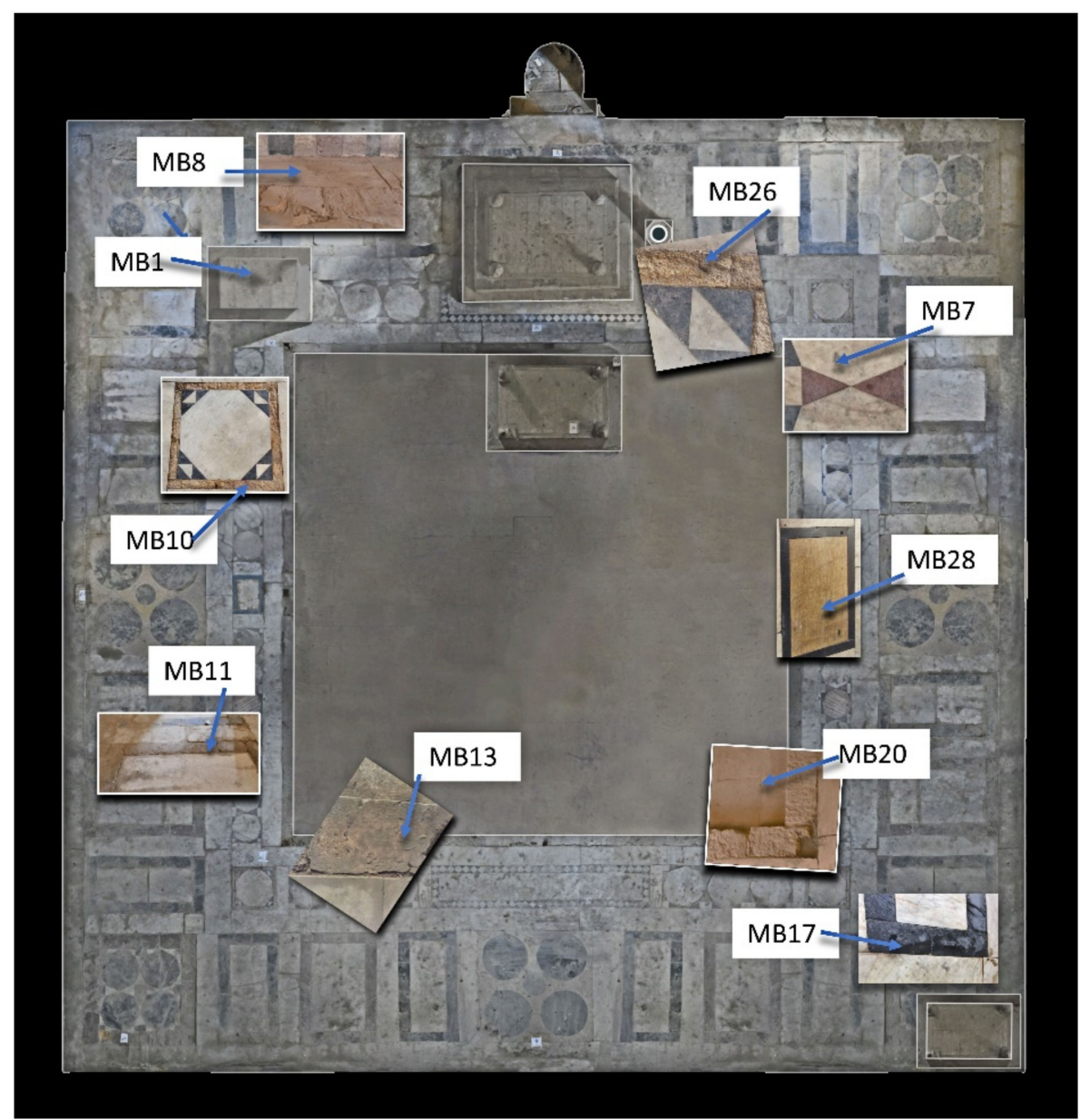

Figure 7. Plan of northern mausoleum pavement, with the position of the collected samples. 


\section{Results}

Most of the sampled stones (13 out of 20), used for the ornamental apparatus of the mihrab's wall and pavement, were attributed, on the base of the mineralogical and petrographic investigation, to carbonate rocks, of both chemical and biochemical origins; the other studied rock samples consist of sandstones and marbles. Figure 8 shows the thin section photomicrographs of representative rock types. A full list of all the identified lithotypes is reported in Table 2, together with the results of the semi-quantitative XRD analyses.

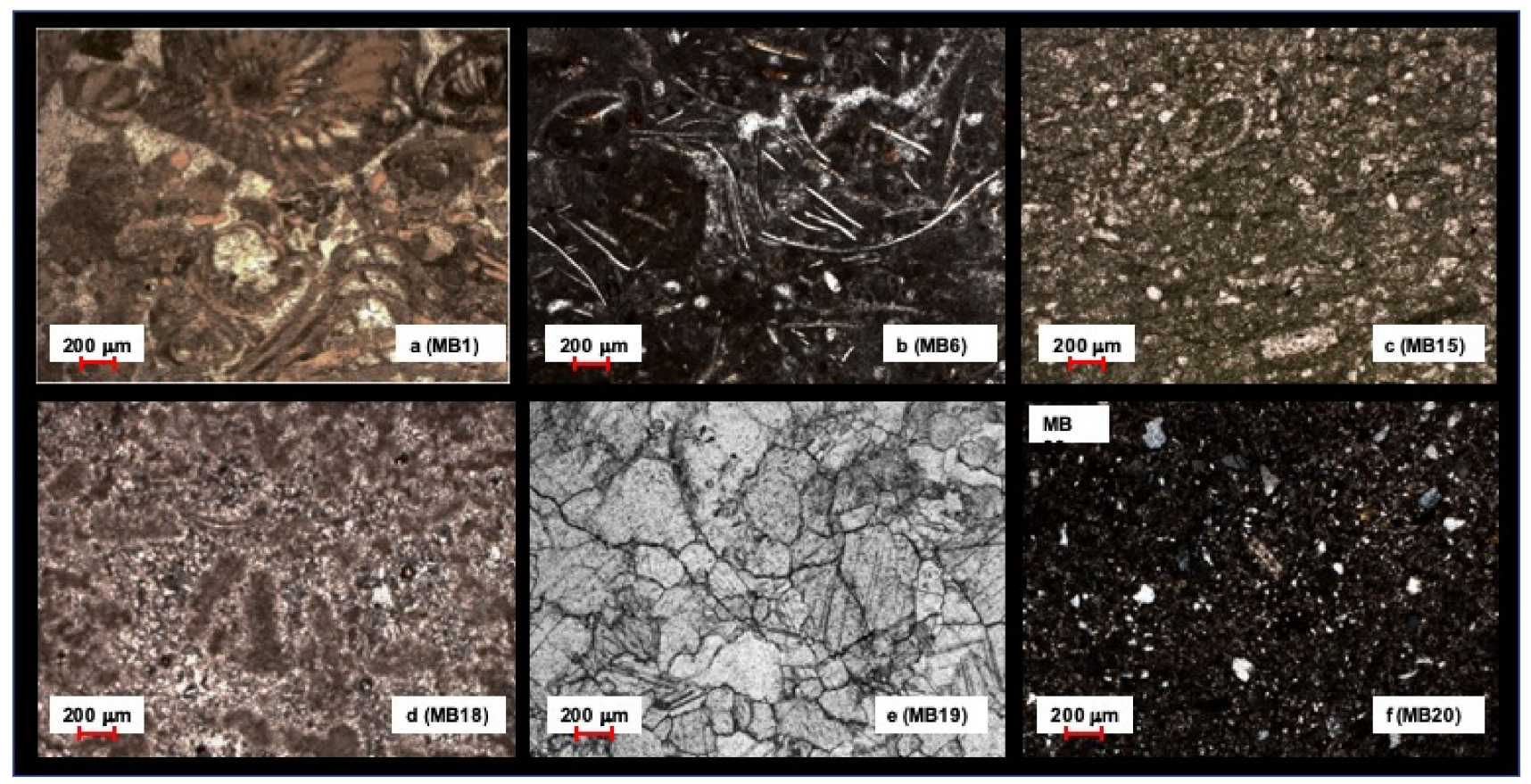

Figure 8. Thin section images of representative rocks used in the decoration of the male mausoleum. (a-d) Carbonate rocks (PPL); (e) marble (PPL); (f) sandstone (XPL).

Table 2. Results of XRD analyses.

\begin{tabular}{|c|c|c|c|c|c|c|c|c|c|c|}
\hline & Sample & Lithotype & Calcite & Quartz & Gypsum & Feldspar & Dolomite & Halite & Mica & Hematite \\
\hline \multirow{5}{*}{$\begin{array}{l}\text { Eastern } \\
\text { wall }\end{array}$} & MB4 & Limestone & $X X X$ & $\operatorname{tr}$ & $\operatorname{tr}$ & - & - & - & - & - \\
\hline & MB6 & Limestone & $X X X$ & $x$ & $X$ & - & - & - & - & - \\
\hline & MB14 & Limestone & $X X X$ & $\operatorname{tr}$ & $\operatorname{tr}$ & - & - & - & - & - \\
\hline & MB18 & Travertine & $X X X$ & - & - & - & - & - & - & - \\
\hline & MB19 & Marble & $X X X$ & - & - & - & - & - & - & - \\
\hline \multirow{5}{*}{ Mirhab } & MB15 & Limestone & $X X X$ & $x$ & - & $\operatorname{tr}$ & - & - & - & - \\
\hline & MB16 & Marble & $X X X$ & - & - & - & - & - & - & - \\
\hline & MB24 & Limestone & $X X X$ & $\operatorname{tr}$ & $x$ & $\operatorname{tr}$ & - & - & - & - \\
\hline & MB25 & Sandstone & - & $X X X$ & $\operatorname{tr}$ & $X$ & $X X$ & $X X$ & - & - \\
\hline & MB27 & Sandstone & $\operatorname{tr}$ & $X X X$ & $\operatorname{tr}$ & $x$ & $X X$ & - & - & - \\
\hline Grave & MB1 & Limestone & $X X X$ & - & - & - & - & $x$ & - & - \\
\hline \multirow{9}{*}{ Floor } & MB7 & Sandstone & $\operatorname{tr}$ & $X X X$ & - & $x$ & $X X$ & $x$ & - & - \\
\hline & MB8 & Limestone & $X X X$ & $\operatorname{tr}$ & - & $\operatorname{tr}$ & - & $X$ & - & - \\
\hline & MB10 & Limestone & $X X X$ & $\operatorname{tr}$ & - & - & $X X$ & $x$ & - & - \\
\hline & MB11 & Limestone & $X X X$ & - & - & - & - & - & $\operatorname{tr}$ & $\operatorname{tr}$ \\
\hline & MB13 & Limestone & $X X X$ & $x$ & $\operatorname{tr}$ & - & - & - & - & - \\
\hline & MB17 & Limestone & $X X X$ & $\operatorname{tr}$ & - & $\operatorname{tr}$ & $X$ & - & - & - \\
\hline & MB20 & Sandstone & - & $X X X$ & - & $x$ & $X X$ & $x$ & - & - \\
\hline & MB26 & Marble & $X X X$ & - & - & - & $x$ & - & - & - \\
\hline & MB28 & Limestone & $X X X$ & $\operatorname{tr}$ & - & - & $x$ & - & - & - \\
\hline
\end{tabular}


The studied biochemical carbonate rocks display variable aspect and colors (yellow, reddish, black), possibly due to the variable content of organism remains, and/or to very low amounts of chromophore elements such as carbon and iron (not detected by XRD analyses except in the sample MB11 where traces of hematite are found). Thin section observations allowed distinguishing different kinds of carbonate rocks (e.g., Figure 8a-c) with porosity variables in shape and size (from medium-low to medium-high) reflecting recrystallization processes. The rocks display a grayish to brownish microcrystalline calcite or a sparry calcite cement and variable content, in some cases very abundant, of different fossils fragments, such as foraminifera and nummulites. According to the Dunham classification [28], it is possible to distinguish mudstones, wackestones, and packstones.

Travertine, used only for the wall decoration, has a whitish color (sample MB18 in Figure 6) and in thin sections display a general massive aspect characterized by small pores, crystals of calcite, and vegetal remains (Figure 8d).

Marbles, white in color (samples MB16 and MB19 in Figure 6), display a prevalent heteroblastic texture with grain boundary shapes from straight to lobate-curved and sutured (Figure 8e). No preferred orientation of the crystals is visible; limited to a few samples, fine-grained calcite crystals can be observed along the grain boundary.

Sandstones, characterized by yellowish-reddish color and small-medium grain size, were used in the male mausoleum for both wall and floor decoration (samples MB7, MB20, MB25, MB27 in Figures 6 and 7). The texture, observed under a polarised microscope, consists of grains from angular to sub-rounded, mainly represented by quartz (50-200 $\mu \mathrm{m}$ in size) and very small, rare feldspar crystals and rock fragments, embedded in a carbonate cement having a dolomitic composition (e.g., MB20 in Figure 8f); according to Folk [29], the sandstones can be classified as sublitharenites.

The composition of limestones, travertine, and marbles consists almost exclusively of calcite; small amounts or traces of other minerals (e.g., quartz, feldspar, dolomite) are also found in almost all the rock samples. Quartz is the dominant constituent of sandstones but, in a lower amount, also dolomite and feldspar are present. In addition to the original constituents of the rocks, other mineral species, such as gypsum and halite, have been detected and deserve further consideration. In Figure 9, X-Ray diffraction patterns, corresponding to the samples, MB 8 and MB 25, are reported. 


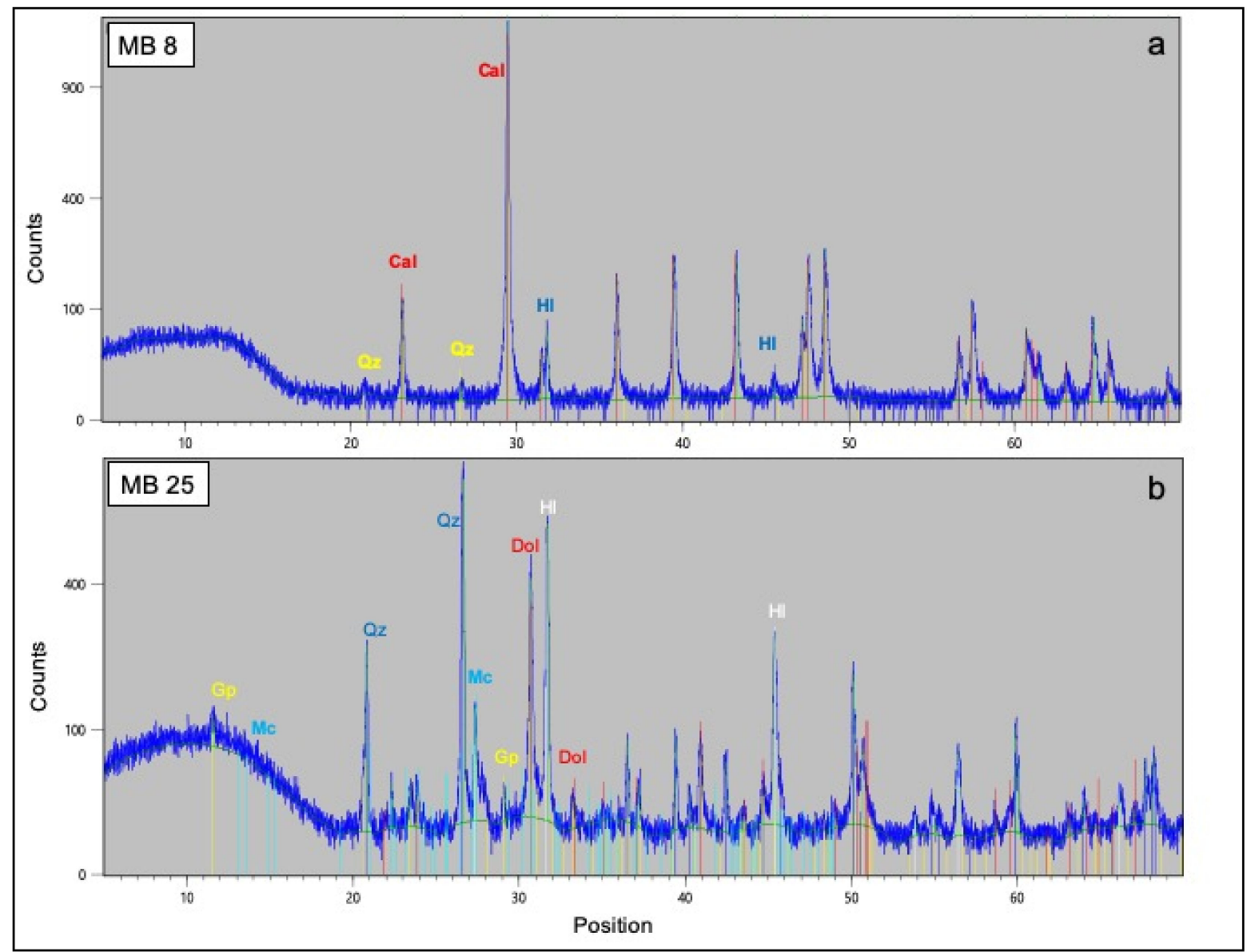

Figure 9. X-ray Diffraction patterns obtained from the samples MB 8 (a) and MB 25 (b). Numbers along the y-axes indicate counts. The different identified compounds are reported in correspondence with the main peaks. Qz $=$ quartz, Cal $=$ calcite, $\mathrm{Hl}=$ halite, $\mathrm{Mc}=$ microcline, $\mathrm{Dol}=$ dolomite .

ATR-FTIR analyses were performed on some samples, to obtain more information on the composition of surface patinas and dust occurring on the studied rocks. The results of the ATR-FTIR investigation are reported in Table 3.

Table 3. Results of the ATR-FTIR analyses.

\begin{tabular}{|c|c|c|c|}
\hline & Sample & Sample Type & ATR-FTIR \\
\hline Eastern wall & $\begin{array}{l}\text { MB2 } \\
\text { MB14 } \\
\text { MB18 } \\
\text { MB19p } \\
\text { MB23 }\end{array}$ & $\begin{array}{l}\text { dust } \\
\text { patina } \\
\text { patina } \\
\text { patina } \\
\text { dust }\end{array}$ & $\begin{array}{c}\text { Silicates, calcite }_{\mathrm{w}} \text {, hydrated and anhydrous sulfates, oxalate } \\
\text { Calcite, silicates, gypsum, oxalate (whevellite) } \\
\text { Calcite, gypsum, silicates, oxalate } \\
\text { Calcite, gypsum, bassanite, oxalates } \\
\text { Calcite, silicates, gypsum, oxalate }{ }_{\mathrm{w}} \text {, organic compounds }\end{array}$ \\
\hline Mirhab & $\begin{array}{l}\text { MB16p }_{p} \\
\text { MB27p }\end{array}$ & $\begin{array}{l}\text { patina } \\
\text { patina }\end{array}$ & $\begin{array}{l}\text { Calcite, silicates, gypsum, oxalate } \\
\text { Silicates, calcite, gypsum, oxalate }\end{array}$ \\
\hline Grave & $\mathrm{MB}_{\mathrm{p}}$ & patina & Calcite, silicates, hydrous sulfates \\
\hline Floor & $\begin{array}{l}\text { MB8 }_{p} \\
\text { MB10 }_{p}\end{array}$ & $\begin{array}{l}\text { patina } \\
\text { patina }\end{array}$ & $\begin{array}{l}\text { Calcite, silicates, gypsum, oxalate } \\
\text { Calcite, silicates, gypsum, oxalate }{ }_{\mathrm{w}}\end{array}$ \\
\hline
\end{tabular}

The subscript " $\mathrm{p}$ " indicates the powders obtained from the surface of rock samples, the subscript " $w$ " indicates weak band(s).

Infrared spectra of the patinas collected from the carbonate rocks exhibit the characteristic absorption peaks of calcite (peaks at 1409,875 , and $715 \mathrm{~cm}^{-1}$ ) and silicates (peaks in the range $1100-1000 \mathrm{~cm}^{-1}$ ) except for the marble MB19 whose composition-according 
to the XRD results-consists only of calcite. In almost all the samples, the characteristic peak of gypsum, centered at $1120 \mathrm{~cm}^{-1}$, is also observed, as well as the distinctive signatures of $\mathrm{O}-\mathrm{H}$ stretching and bending vibrations at 3400, 3530, and at 1620 and $1680 \mathrm{~cm}^{-1}$, respectively, and that of calcium oxalate (peaked at $1324 \mathrm{~cm}^{-1}$ ).

ATR-FTIR analysis was performed also on the MB27 $p$ and two samples of dust (MB2 $p$ and MB23 ) (Table 3). The observed silicate peak in the MB27 powder is imputable to the underlying rock (sandstone) whereas we have to assume a different origin for silicates and calcite in $\mathrm{MB}_{\mathrm{p}}$ and MB23 samples. Moreover, the ATR-FTIR analyses revealed the presence of sulfate and oxalate in $\mathrm{MB} 2 \mathrm{p}$ and $\mathrm{MB} 27_{p}$; finally, the sample $\mathrm{MB}_{2} 3_{\mathrm{p}}$ contains also organic matter showing in the corresponding spectrum the weak bands at $2919 \mathrm{~cm}^{-1}$ and $2850 \mathrm{~cm}^{-1}$ attributed to the stretching of $\mathrm{CH}_{3}$ and $\mathrm{CH}_{2}$ groups. Figure 10 shows the spectra obtained for the samples MB23 $3_{\mathrm{p}}$ and $\mathrm{MB} 10_{\mathrm{p}}$.

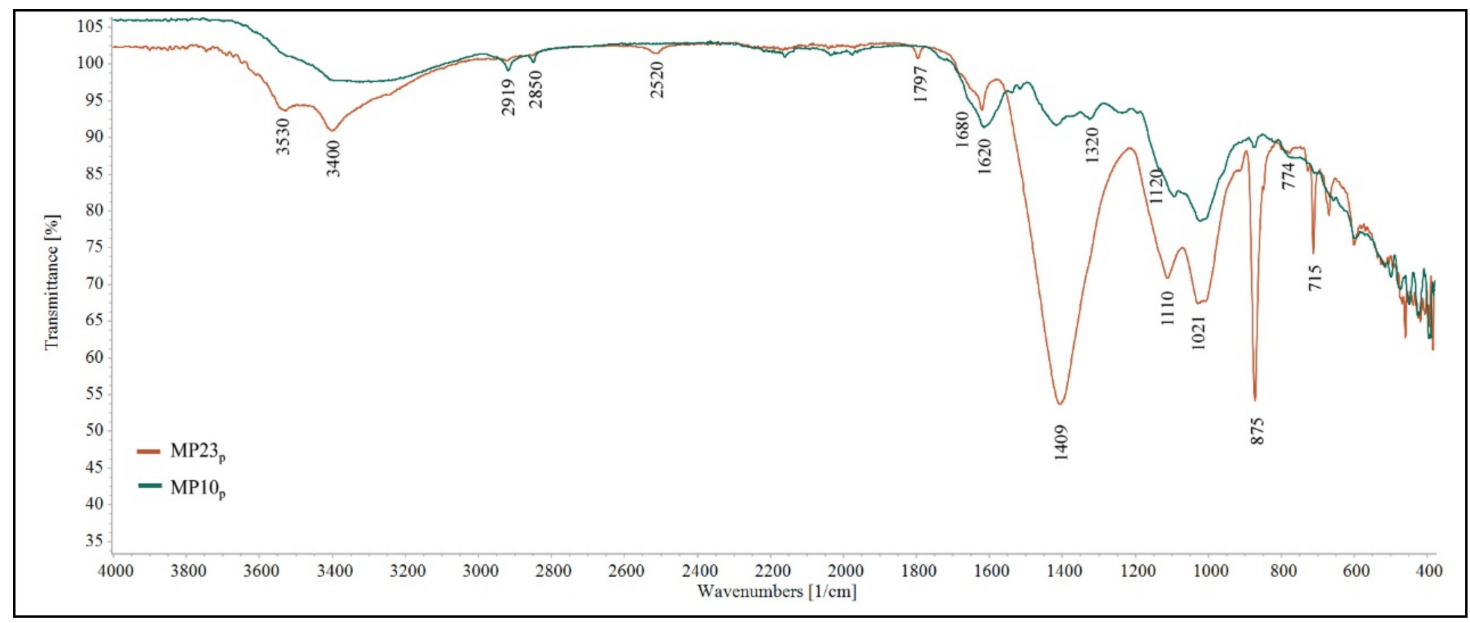

Figure 10. Transmission ATR-FTIR spectra of the samples MP23 and MP10 , showing the presence of calcite $(1409,875$, and $715 \mathrm{~cm}^{-1}$ and 1797 and $2520 \mathrm{~cm}^{-1}$ ), silicates (peaks in the range 1100-1000 $\mathrm{cm}^{-1}$ ), gypsum $(1120,1620,1680,3400$ and $3500 \mathrm{~cm}^{-1}$ ) and oxalate $\left(774\right.$ and $\left.1320 \mathrm{~cm}^{-1}\right)$. The MP23 $\mathrm{p}$ contains also organic matter $\left(2919\right.$ and $\left.2850 \mathrm{~cm}^{-1}\right)$.

\section{Discussion and Concluding Remarks}

The northern mausoleum of Al-Nasir Faraj Ibn Barquq suffered steady abandonment and displays evidence of severe decay. The first identified degradation factor is surely the rising groundwater, often rich in salts as sulfates and chlorides. This phenomenon is well described and widespread in the whole urban area of Cairo and its effects are evident in all the historic buildings of the city, particularly in the North East area, between the city and the Moqattam hills $[11,16,30]$. The relatively recent phenomenon of the rising waters is generally attributed to increased anthropic pressure in the region, related to increased extraction of underground fossil waters (i.e., waters not connected to the surficial systems) and their subsequent partial dispersion in surficial or sub-surficial systems. This results in the rising of the water table, which, in turn, permeates building foundations. This scenario also holds for the Barquq's complex. It was built in an originally desertic area but is now enclosed by a dense conurbation. So, the capillary rise could be closely linked to the urban drift to which the Al-Qarafa Al-Kubra area has been subjected to the last decades. Further considerations on the speed of degradation promoted by the rise of the water table are prevented by the replacement of some building and decorative stones operated (and poorly documented) since the last 60 years.

In addition to the capillary rise of water, other forms of degradation affected the building. Mineralogical analyses of the collected samples revealed the presence of compounds (sulfates, halite, oxalates) that can be linked to various decay processes. The action of water, infiltration or condensation, is causing the detachment of the layers of plaster on the intrados of both the brick domes of the eastern iwan and the large stone dome of the 
northern mausoleum. Environmental humidity combined with other atmospheric factors could be at the basis of the deterioration of many pictorial layers of the mausoleum. In the entire architectural complex, also phenomena of decay of the masonry (e.g., in many parts of the khanqah reduced to a state of ruin) and localized damage (abrasion, pollution due to accumulation of waste) have occurred. The absence of adequate protection and, above all, of system maintenance is crucial in the evolution of these phenomena, which remain constantly out of control.

Air pollution represents a relevant additional risk factor for the stone building decay, especially if coupled to the capillary rise of water. An $\mathrm{SO}_{2}$-rich atmosphere [31-33] can be responsible for the sulphation mechanisms in different types of rocks. Indeed, the crystallization of soluble salts within the pores of the stone is a well-known mechanism able to cause the deterioration of building stones, through the consequent increase of pressure on the rock grains; this can be responsible for the mechanical disintegration of the building materials.

A more complex situation concerns the abundant presence of halite found in both the XRD and ATR-FTIR results. This phase can be linked to a side effect of the capillary rise of waters from the underground, which could be highly saline, due to the lack of sewage systems or leaking [16]. Indeed, this phenomenon has been already highlighted at the exterior of the Faraj's complex [16,32-34]. On the other hand, also the atmosphere can be considered as an additional source, being in Cairo rich enough of sulfate species (mainly due to anthropic activities) and sodium chloride (by transport from the near-desert regions [31] and seas [32]).

We propose that both phenomena of contamination by chloride salts are effective also indoor. Accordingly, the indoor and outdoor atmospheres have to be considered as a unique system, even if some peculiar physical conditions exist in the indoor system. It may be concluded that the chemical deterioration of the stones relies on the combination of capillary rise of water and airborne pollution. This conclusion is even more relevant if one considers that most of the materials surveyed and sampled in this study consist of various carbonate stones, which can be easily affected by these phenomena.

The presence of oxalate films (mainly calcium-oxalate) on stone monuments was largely documented since the description of Justus Von Liebig in 1853 [35] and is now widely known. Oxalates usually form, on the stone buildings and artifacts materials, a patina whose origin is still unclear. The scientific debate concerns three main causes, i.e., (1) a precipitation mechanism involving the reaction between metabolically produced oxalic acid by lichens and other micro-organisms and Ca-bearing building materials [36], (2) an anthropogenic origin for the oxalic acid from airborne pollutant of the atmosphere [37] and (3) a transformation of past conservation treatments (e.g., waxes, oil, Arabic gum, milk, glue), applied to stone surfaces, to calcium oxalate $[38,39]$. In the case of Faraj's northern mausoleum, none of the possible causes can be excluded. The oxalate films have been found on the surface of both carbonate rocks and sandstone, each containing calcium (Tables 2 and 3). In principle, the high air pollution in Cairo could explain the presence of calcium oxalate; in fact, the building materials can entrap compounds such as oxalic acid, present in the air as a photo-oxidation product of gas from vehicle emissions. Its reaction with carbonate substrate of built heritage could yield calcium oxalate [39]. However, although biological coatings were not macroscopically identified during the survey, we cannot exclude an important role of the organisms (fungi, cyanobacteria, lichens) in the genesis of oxalate patinas. Similarly, we cannot rule out the possibility that the detected oxalate is a residue of past conservation treatments.

The results of the present research open a further interesting perspective: there is no documented information of interventions carried out on the qibla wall. From a survey carried out in 1996 [15], Harrell reports an almost total replacement of the original stone decorative apparatus. However, a more heterogeneous situation emerges from a comparison between the photographic documentation found [24,35] and the current state. Some images from 1932 partially document an advanced state of degradation of some 
portions of the coating near the mihrab [40]. These problems do not appear in the successive partial photographic documentation made in 1968 [24]. This would indicate that some repairs/replacements may have been carried out in the decades between 1932 and 1968 . On the other hand, the current situation is also different compared to the conditions of the 1960s: the position of some slabs appears unchanged but, in different areas of the wall, the observed variations in the chromatic sequences of the slabs and in the geometry suggest punctual replacements. Further systematic investigation campaigns will allow more detailed identification of the original and replaced materials while attempting to finally assess their provenance.

Author Contributions: Conceptualization, A.P.S., F.D.B., M.C.; methodology, A.P.S., C.A.G., F.D.B., M.C.; on field data collection, C.A.G., M.C., F.D.B., T.S., and A.P.S.; investigation (FT-IR) T.S.; investigation (petrographic and XRD), A.P.S., E.P.; investigation (historical sources and architectural investigation), M.C.; data curation, F.D.B., M.C., A.P.S., T.S., E.P.; writing—original draft preparation, A.P.S., F.D.B., M.C.; writing-review and editing, A.P.S., F.D.B., M.C., E.P., T.S.; supervision, C.A.G., F.D.B.; project administration, C.A.G.; funding acquisition, A.P.S., F.D.B., C.A.G., M.C. All authors have read and agreed to the published version of the manuscript.

Funding: This research was funded by Progetto di Ateneo (ex 60\%) to FDB $(2018,2019)$ and M.C. (2020), and by Fondi di Internazionalizzazione to F.D.B., A.S., C.A.G. $(2018,2019)$ and M.C. (2019). All these funds were provided by the Università degli Studi di Firenze.

Data Availability Statement: Not applicable.

Acknowledgments: The authors want to express their warmest thanks to the General Union of Arab Archaelogists (Cairo, Egypt) and specifically to Mohamed Mohamed El Kahlawey, thanks to whose assistance, the survey was made possible. The authors also benefited of fruitful scientific discussion with Mohamed Mohamed El Kahlawey, Saleh Lamei Mostafa, Gamal, concerning technical historical and artistic details of the Khanqah and of the Mamluk and Medieval monuments in Cairo, in general. The authors are also indebted to the General Union of Arab Archaeologists (Cairo, Egypt) for the kind hospitality received. Logistic support to the survey was also provided by the El Kahlawey's staff members, to whom the authors express their warmest thanks. The authors are indebted to Mahmoud Salem Elsheikh, who promoted and supported the collaboration between the Università degli Studi di Firenze and the General Union of Arab Archaologists; Elsheikh was also deeply involved in supporting any aspect of the survey in Cairo. This study would be never made possible without his enthusiastic contribution.

Conflicts of Interest: The authors declare no conflict of interest. The funders had no role in the design of the study; in the collection, analyses, or interpretation of data; in the writing of the manuscript, or in the decision to publish the results.

\section{References}

1. Rabbat, N. Mamluk History through Architecture. Monuments, Culture and Politics in Medieval Egypt and Syria; I.B. Tauris: Cairo, Egypt; New York, NY, USA, 2010.

2. Bierman, I. Art and Architecture in the Medieval period. In The Cambridge History of Egypt; Islamic Egypt; Petry, C.F., Ed.; Cambridge University Press: Cambridge, UK, 1998; Volume 1, pp. 339-374.

3. Nicholson, P.T.; Shaw, I. Ancient Egyptian Materials and Technology, 1st ed.; Cambridge University Press: Cambridge, UK, 2000.

4. Yeomans, R. The Art and Architecture of Islamic Cairo, 1st ed.; Garnet Publishing Limited: Reading, UK, 2006.

5. Behrens-Abouseif, D. Cairo of the Mamluks: A History of Architecture and Its Culture; I.B. Tauris: London, UK; New York, NY, USA, 2007.

6. Sanders, P. Creating Medieval Cairo. Empire, Religion and Architectural Preservation in Nineteenth Century Egypt; American University: Cairo, Egypt, 2008.

7. Antoniou, J.; Bianca, S.; El Hakim, Sh.; Lewcock, R.; Welbank, M. The Conservation of the Old City of Cairo; UNESCO: Paris, France, 1985.

8. Aly, N.; Gomez-Heras, M.; Hamed, A.; Álvarez de Buergo, M.; Soliman, F. The influence of temperature in a capillary imbibition salt weathering simulation test on Mokattam limestone. Mater. Constr. 2015, 65, 317. [CrossRef]

9. Mostafa, A.N.; Zakey, A.S.; Alfaro, S.C.; Wheida, A.A.; Monem, S.A.; Wahab, M.M.A. Validation of RegCM-CHEM4 model by comparison with surface measurements in the Greater Cairo (Egypt) megacity. Environ. Sci. Pollut. Res. 2019, $26,23524-23541$. [CrossRef] [PubMed] 
10. Masuch-Oesterreich, D. The groundwater rise in the east of Cairo and its impact on historic buildings. In Geoscientific Research in Northeast Africa, Rotterdam, Balkema, 17 June 1993; Schandelmeier, H., Thorweihe, U., Balkema, A.A., Eds.; Brookfield: Rotterdam, The Netherlands, 1993; pp. 713-719.

11. Shaltout, A.A.; Boman, J.; Hassan, S.K.; Abozied, A.M.; Al-Ashkar, E.A.; Abd-Elkader, O.H.; Yassin, M.A.; Al-Tamimi, J.H. Elemental Composition of PM2.5 Aerosol in a Residential-Industrial Area of a Mediterranean Megacity. Arch. Environ. Contam. Toxicol. 2020, 78, 68-78. [CrossRef] [PubMed]

12. El-Metwally, A.A.; Ramadan, A.B. The role of air pollutants and sewage waste in acceleration of degradation of the Islamic cultural heritage of Cairo. In Comparative Risk Assessment and Environmental Decision Making; Linkov, I., Ramadan, A.B., Eds.; NATO Science Series: IV: Earth and Environmental Sciences; Springer: Berlin/Heidelberg, Germany, 2005; Volume 38, pp. 363-370. [CrossRef]

13. Bianca, S.; Jodidio, P. Cairo. Revitalizing a Historic Metropolis; Aga Khan Trust for Culture, Turin: Berlin, Germany; Umberto Allemandi \& Co. Publishing: Turin, Italy, 2004.

14. Comité de Conservation des Monuments de l'Art Arabe. Khankah de Farag ibn Barkūk 801-813 H. (1398-1411 A.D.). In Procès-Verbaux des Séances du Comité et Rapports de la Section Technique; Exercice 1946-1953; Fascicule 40; Organisme Général des Imprimeries Gouvernementales: Cairo, Egypt, 1961; pp. 337-339.

15. Harrell, J.A. Survey of Ornamental Stones in Mosques and Other Islamic Buildings of the Pre-Ottoman Period in Cairo, Egypt. Available online: http:/ / www.eeescience.utoledo.edu/ (accessed on 4 November 2019).

16. Coppola, M.; Di Benedetto, F.; Garzonio, C.A.; Pecchioni, E.; Santo, A.P. Groundwater damages on the historic buildings of Cairo: The case of the medieval walls of Mokattam limestone. In HERITECH 2020, Proceedings of the International Conference Florence Heri-Tech: The Future of Heritage Science and Technologies, 14-16 October 2020; IOP Conference Series-Materials Science and Engineering; IOP: Bristol, UK, 2020; Volume 949, pp. 1-8. [CrossRef]

17. Behrens-Abouseif, D. Islamic Architecture in Cairo: An Introduction; E.J. Brill: Leiden, The Netherlands; New York, NY, USA, 1989.

18. Behrens-Abouseif, D. Cairo of the Mamluks: A History of Architecture and its Culture; I.B. Tauris: London, UK, 2008.

19. Rabbat, N. The Citadel of Cairo: A New Interpretation of Royal Mamluk Architecture; E.J. Brill: Leiden, The Netherlands; New York, NY, USA, 1995.

20. Dobrowolski, J. The Living Stones of Cairo; The American University in Cairo Press: Cairo, Egypt; New York, NY, USA, 2001.

21. Jarrar, S.; Riedlmayer, A.; Spurr, J.B. Resources for the Study of Islamic Architecture; Aga Khan Program for Islamic Architecture: Cambridge, UK, 1994.

22. Williams, C. Islamic monuments in Cairo. In The Practical Guide, 7th ed.; The American University in Cairo Press: Cairo, Egypt; New York, NY, USA, 2018.

23. Popper, W. Egypt and Syria Under the Circassian Sultans, 1382-1468 A.D.: Systematic Notes to Ibn Taghrî Birdî's Chronicles of Egypt; University of California Press: Berkeley, CA, USA, 1955; Volume 2.

24. Mostafa, S.L.; Augustin, J.J. Kloster und Mausoleum des Farag Ibn Barquq in Kairo. Augustin, J.J.: Glückstadt, Germany, 1968.

25. Cardarelli, F. Encyclopaedia of Scientific Units, Weights, and Measures: Their SI Equivalences and Origins; Springer: London, UK; New York, NY, USA; Heidelberg, Germany, 2003.

26. Patricolo, A. Mausolées des sultans Barqouq et Farag, au cimetière est (803-813 H. = 1400-1410 A. D.). In Comité de Conservation des Monuments de l'Art Arabe; Fascicule 32; Exercice, 1915-1919; Institut Français D’archéologie Orientale: Cairo, Egypt, 1922; pp. 120-121.

27. Greg, R.H.; Sulayman, H.; Wiet, G.; Farid, A.; Ahmad, M. Khankah de Farag ibn Barkūk, In: Comité de Conservation des Monuments de l'Art Arabe. Fascicule 38, Exercice 1940, 215, 1944.

28. Dunham, R.J. Classification of carbonate rocks according to depositional texture. In Classification of Carbonate Rocks; Ham, W.E., Ed.; AAPG Memoir: Tulsa, OK, USA, 1962; Volume 1, pp. 108-121.

29. Folk, R.L. Petrology of Sedimentary Rocks; Hemphill Publishing Company: Austin, TX, USA, 1974.

30. Fitzner, B.; Heinrichs, K.; La Bouchardiere, D. Limestone Weathering of Historical Monuments in Cairo, Egypt. In Natural Stone, Weathering Phenomena, Conservation Strategies and Case Studies; Geological Society Special Publication No., 205, Siegesmund, S., Vollbrecht, A., Weiss, T., Eds.; Geological Society: London, UK, 2002; pp. 217-239. [CrossRef]

31. Hindy, K.T.; Baghdady, A.R.; Howari, F.M.; Abdelmaksoud, A.S. A Qualitative Study of Airborne Minerals and Associated Organic Compounds in Southeast of Cairo, Egypt. Int. J. Environ. Res. Public Health 2018, 15, 568. [CrossRef] [PubMed]

32. Rovella, N.; Aly, N.; Comite, V.; Ruffolo, S.A.; Ricca, M.; Fermo, P.; Alvarez de Buergo, M.; La Russa, M.F. A methodological approach to define the state of conservation of the stone materials used in the Cairo historical heritage (Egypt). Archeol. Anthropol. Sci. 2020, 12, 178. [CrossRef]

33. Rovella, N.; Aly, N.; Comite, V.; Randazzo, L.; Fermo, P.; Barca, D.; Alvarez de Buergo, M.; La Russa, M.F. The environmental impact of air pollution on the built heritage of historic Cairo (Egypt). Sci. Total Environ. 2021, 764, 142905. [CrossRef] [PubMed]

34. Lowenthal, D.H.; Gertler, A.W.; Labib, M.W. Particulate matter source apportionment in Cairo: Recent measurements and comparison with previous studies. Int. J. Sci. Environ. Technol. 2014, 11, 657-670. [CrossRef]

35. Liebig, J. Ueber den Thierschitt; Annal Chemie Pharm LXXXVI: Leipzig, Germany; Heidelberg, Germany, 1856 ; pp. $113-115$.

36. Del Monte, M.; Sabbioni, C.; Zappa, G. The origin of calcium oxalates on historical buildings, monuments and natural outcrops. Sci. Total Environ. 1987, 67, 17-39. [CrossRef] 
37. Saiz-Jimenez, C. Biogenic vs. anthropogenic oxalic acid in the environment. In Proceedings of the International Symposium "The Oxalate Films: Origin and Significance in the Conservation of Works of Art", Milan, Italy, 25-26 October 1989; Centro “Gino Bozza": Milano, Italy, 1989; pp. 207-214.

38. Lazzarini, L.; Salvadori, O. A reassessment of the patina called 'scialbatura'. Stud. Conserv. 1989, 34, 20-26. [CrossRef]

39. Rampazzi, L. Calcium oxalate films on works of art: A review. J. Cult. Herit. 2019, 40, 195-214. [CrossRef]

40. Hautecoeur, L.; Wiet, G. Les Mosquées du Caire; Librairie Ernest Leroux: Paris, France, 1932. 